\title{
A USUCAPIÃO EXTRAJUDICIAL: A CONTRADIÇÃO DO SILÊNCIO COMO DISCORDÂNCIA
}

\section{THE EXTRAJUDICIAL BRAZILIAN USUCATION: THE CONTRADICTION OF SILENCE AS A DISCORDANCE}

\author{
${ }^{1}$ Marcelo Lessa da Silva
}

\section{Resumo}

O presente trabalho objetivou analisar a possibilidade do reconhecimento da usucapião pela via extrajudicial. Utilizou-se do método de pesquisa teórico-dogmático, exploratório e explicativo, adotando-se uma pesquisa jurídica e social, com técnica de coleta e análise documental e bibliográfica. Concluiu-se pela sua ineficácia como disposta pela lei, por retirar do registrador a possibilidade do reconhecimento da usucapião diante da ausência expressa de concordância de qualquer um dos titulares de direitos reais ou de outros direitos registrados ou averbados na matrícula do imóvel usucapiendo ou nas matrículas dos imóveis confrontantes.

Palavras-chave: Usucapião Extrajudicial; Serventias extrajudiciais; Silêncio como discordância; Direito de propriedade

\begin{abstract}
The present paper aimed to analyze the possibility of the recognition of usucation brazilian through the extrajudicial meaning. The method of theoretical-dogmatic research, exploratory and explanatory was used, adopting a juridical and social research, with technique of collect and documentary and bibliographic analysis. It was concluded by its ineffectiveness as provided by law, to withdraw from the registrar the possibility of recognition of usucation brazilian in the absence of express agreement of any of the holders of real rights or other rights registered or endorsed in the registration of property that use the usucation brazilian or in registrations confronting properties.
\end{abstract}

Keywords: Extrajudicial brazilian usucation; Extrajudicial services; Silence as disagreement; Property rights

\section{INTRODUÇÃO}

\footnotetext{
${ }^{1}$ Professor de Direito da Universidade Federal do Rio de Janeiro, UFRJ - RJ, (Brasil).Mestrando em Direito na Universidade Veiga de Almeida, UVA - RJ, (Brasil). E-mail: marcelolessa.federal@ yahoo.com.br
} 
O direito brasileiro vive um momento de muitas transformações. Nos últimos anos houve um aumento quantitativo das demandas judiciais fomentadas pelo contínuo processo de amadurecimento da democracia, levando o cidadão ao pleno exercício de seus direitos e utilizando-se do judiciário para sua garantia. Esse aumento gerou uma sobrecarga no sistema judiciário, resultando na morosidade e, consequentemente, na falta de efetividade deste sistema.

Com vistas a melhorar o atendimento e desafogar o sistema judicial, o processo de desjudicialização vem ganhando espaço no Brasil. Alguns institutos foram ampliados, possibilitando às partes resolver a demanda de forma extrajudicial, ou seja, através de um processo administrativo utilizando para tanto os serviços dos notários e oficiais de registros públicos. As demandas desjudicializadas são inerentes a ações de jurisdição voluntária e que, em regra, requerem do Estado uma sentença declaratória, ou seja, de reconhecimento. Como exemplo, tem-se o divórcio, a separação, o inventário e a partilha, a usucapião no âmbito da regularização fundiária de interesse social, a mediação de conflitos e a retificação de registro.

Nesse movimento o legislador brasileiro traz outra inovação. Desta vez, o instituto que entrou para o grupo de possibilidades de processamento pela via extrajudicial, foi o da usucapião. A possibilidade do reconhecimento da usucapião pela via extrajudicial, através de processo administrativo realizado diretamente no registro de imóveis, foi introduzida no ordenamento jurídico brasileiro pelo novo Código de Processo Civil (Lei no 13.105/15), incluindo o artigo 216-A na Lei de Registros Públicos (Lei no 6.015/73).

É sem dúvida um grande avanço no caminho de garantir a celeridade no reconhecimento estatal de um direito já adquirido por disposição legal ou constitucional, a depender da modalidade de usucapião, mas, que necessita deste reconhecimento estatal para a substituição dominial no assentamento registral.

Neste processo brasileiro de desjudicialização, as serventias extrajudiciais é o locus adequado para proporcionar, além da celeridade procedimental, a redução dos custos da máquina judiciária e maior acesso à justiça.

As serventias extrajudiciais, sem se afastar dos princípios que norteia a função pública, imprimem segurança jurídica aos atos praticados, e ainda, possuem a capilaridade para aumentar consideravelmente o locus de realização do procedimento de reconhecimento da usucapião, tais como todos os demais atos e procedimentos desjudicializados e atribuídos aos cartórios. 
Entretanto, os legisladores do Senado Federal, por insegurança ou falta de confiança na atuação dos notários e registradores, ou então, preferindo privilegiar o direito de propriedade, mesmo a que não cumpra a função social, resolveu no âmbito da usucapião extrajudicial interpretar o silêncio/inércia do titular dominial, diante de uma notificação, como discordância ao processamento da usucapião, inviabilizando sua efetivação na via extrajudicial e devendo ser processada, necessariamente, na via judicial.

Neste contexto apresentado é que se desenvolveu a pesquisa. Objetivou-se no curso deste estudo apresentar e analisar estas questões. Para tanto, utilizou-se do método de pesquisa teórico-dogmático, exploratório e explicativo, adotando-se uma pesquisa jurídica e social, com técnica de coleta e análise documental e bibliográfica.

\section{O DIREITO DE PROPRIEDADE}

Torna-se relevante primeiramente destacar que em um país de fortes traços patrimonialistas, a Constituição Federal de 1988 trouxe em seu artigo 5, XXII a proteção ao direito de propriedade. Contudo, a propriedade não tem mais o caráter absoluto que outrora tivera, pois diante da conjuntura contemporânea o constituinte de 1988 impôs à propriedade o dever do cumprimento de sua função social, logo em seguida, no inciso XXIII. Aliás, essa técnica legislativa adotada pelo constituinte, pode ser observada também no artigo 170, onde ao tratar da ordem econômica e financeira, elencando seus princípios gerais, apresenta o princípio da propriedade privada no inciso II, e logo a seguir, no inciso III, apresenta também como princípio a ser observado, a função social da propriedade.

A Constituição de 1988 só garante o direito de propriedade, desde que este exerça sua função social, ou seja, a propriedade traz ao seu titular um dever de usá-la visando um fim social. O texto constitucional determina a funcionalidade da propriedade, ao colocar a dignidade da pessoa humana como alicerce da República e originar como desígnio a justiça social.

A função social, deste modo, implica que, ao lado das vantagens de usar, gozar e dispor do bem, o proprietário passa a ter não somente limites ao exercício do seu direito, mas ainda comprometimentos positivos em benefício da coletividade. Portanto, a função social não deseja somente abolir as condutas antissociais, mas ainda direcionar e guiar o comportamento do titular para a realização do interesse público. 


\section{DA USUCAPIÃO}

A aquisição da propriedade imóvel encontra-se disciplinada nos artigos 1.238 a 1.259 e 1.784 do Código Civil Brasileiro; podendo ocorrer por meio da usucapião, do registro do título translativo na serventia imobiliária, da acessão e, por fim, da sucessão hereditária.

Quanto à usucapião, objeto do nosso estudo, é modo originário de aquisição da propriedade e de outros direitos reais através da posse prolongada e qualificada segundo os requisitos previamente estabelecidos em lei, onde dois elementos estarão sempre presentes qualquer que seja a modalidade de usucapião, o tempo e a posse.

Não basta a posse normal (ad interdicta), mas sim, a posse ad usucapionem onde, além da visibilidade do domínio, a posse do usucapiente apresenta qualidades específicas, quais sejam, uma posse mansa e pacífica (sem oposição), contínua (sem interrupção), com animus domini (com o ânimo de dono/ter como seu o imóvel), e ainda, pelo transcurso do tempo definido em lei.

Para Orlando Gomes (2012, p. 179,180), a usucapião é um instituto autônomo, e não atrelado ao conceito de prescrição, em uma forma aquisitiva ou positiva ao lado da prescrição extintiva ou liberatória; é, portanto, um dos modos de aquisição da propriedade e de outros direitos reais, autonomamente consagrada nas legislações modernas, e por diversos fundamentos, conclui que não há que se falar em prescrição aquisitiva para o instituto da usucapião, apesar de se aproximarem e manterem ostensivos pontos de semelhança. É, portanto, um modo de aquisição da propriedade pela posse continuada durante certo lapso de tempo, com os requisitos estabelecidos em lei, por via do qual o possuidor se torna proprietário de maneira originária, pois a despeito de acarretar a extinção do direito de propriedade do antigo titular, não se estabelece qualquer vínculo entre ele e o possuidor usucapiente.

Já para Roberto Gonçalves (2015, p. 518) a usucapião também pode ser chamada de prescrição aquisitiva, em confronto com a prescrição extintiva, pois em ambos aparece o elemento tempo a influir na aquisição ou na extinção de direitos. Define, portanto, a Usucapião ou prescrição aquisitiva como modo originário de aquisição da propriedade e de outros direitos reais suscetíveis de exercício continuado pela posse prolongada no tempo, presentes os requisitos legais. Na defesa de sua posição doutrinária apresenta o Art. 1.244 do CCB onde o legislador estendeu ao possuidor ad usucapionem as causas que obstam, suspendem e 
interrompem a prescrição extintiva. ${ }^{2}$

Nesse sentido é também o posicionamento do STJ. Vejamos:

PROCESSUAL CIVIL E CIVIL. AGRAVO REGIMENTAL. RECURSO ESPECIAL. FUNDAMENTAÇÃO, APENAS, NA ALÍNEA C DO PERMISSIVO CONSTITUCIONAL. USUCAPIÃO. PRESCRIÇÃO AQUISITIVA. INTERRUPÇÃO DO RESPECTIVO PRAZO NÃO VERIFICADA. AÇÃO POSSESSÓRIA JULGADA IMPROCEDENTE. JURISPRUDÊNCIA. ENUNCIADO N. 83 DA SÚMULA DO STJ. 1.

Impõe-se o não conhecimento do presente recurso especial, assentado apenas no art. 105 , III , c , da CF/1988, porquanto a jurisprudência atual desta Corte, diversamente da tese invocada pelos agravantes, converge no sentido de que a citação efetuada em ação possessória julgada improcedente não interrompe o prazo para a prescrição aquisitiva (usucapião). Incidência do enunciado n. 83 do STJ. 2. Agravo regimental desprovido. STJ - AGRAVO REGIMENTAL NO RECURSO ESPECIAL AgRg no REsp $1010665 \mathrm{MS}$ 2007/0280132-4 (STJ) - Data de publicação: 21/10/2014 (grifo nosso)

Temporais. $2.2 \mathrm{Na}$ prescricão aquisitiva, ou usucapião, é indispensável que o postulante alegue seu direito, quer por via de ação própria, quer por exceção de domínio, nos termos da súmula 237/STF, "o usucapião pode ser arguido em defesa", não sendo dado ao magistrado declará-lo de ofício mediante a invocação do art. $219, \S 5^{\circ}$, do CPC. O momento para a arguição da prescricão aquisitiva, sob pena de preclusão, é na contestação, uma vez que ante o princípio da igualdade das partes no processo, consoante o art. 128 do CPC, deve o juiz decidir a lide nos limites em que foi proposta, sendo-lhe defeso conhecer de questões não suscitadas a cujo respeito a lei exige a iniciativa da parte. STJ - RECURSO ESPECIAL REsp 1106809 RS 2008/0260795-5 (STJ) - Data de publicação: 27/04/2015. (grifo nosso)

Portanto, verifica-se na jurisprudência que o instituto da usucapião ora é tratado como sinônimo de prescrição aquisitiva, ora é tratado como consequência deste, ou seja, para o reconhecimento da usucapião faz-se necessário à constatação da prescrição aquisitiva, verificando-se, além dos requisitos definidos em lei para a aquisição da propriedade pela usucapião, a não ocorrência das causas que obstam, suspendem ou interrompem a prescrição aquisitiva.

\section{1. PRESSUPOSTOS COMUNS DA USUCAPIÃO}

Os pressupostos comuns da usucapião são aqueles indispensáveis a todas as modalidades de usucapião, sem os quais é impossível se falar na sua ocorrência, muito menos na possibilidade de seu reconhecimento pelo Estado. Três são os pressupostos necessários ou

\footnotetext{
${ }^{2}$ Art. 1.244 do CCB. Estende-se ao possuidor o disposto quanto ao devedor acerca das causas que obstam, suspendem ou interrompem a prescricão, as quais também se aplicam à usucapião. (grifo nosso)
} 
essenciais para todas as espécies de usucapião: a coisa hábil (res habilis), trata- se do bem passível de prescrição aquisitiva, ou seja, todos aqueles que não são impedidos de usucapir, como os bens públicos (Art. 183, $\$ 3^{\circ}$ da CRFB/1988); os de titularidade dos absolutamente ou relativamente incapazes (Art. 197 e 198 do CC/2002); e, os fora do comércio. A posse ad usucapionem, que se constitui numa posse com qualidades específicas, devendo ser exercida de forma mansa e pacífica (sem oposição), contínua (sem interrupção), e, com animus domini, com o ânimo de dono (de ter como sua a coisa). E, por fim, o lapso temporal que é o transcurso de tempo contínuo definido em lei, a depender da modalidade, que pode variar, segundo o ordenamento jurídico brasileiro, de 2 (dois) anos, no caso da Usucapião Familiar, à 15 (quinze) anos, no caso da Usucapião Extraordinária. Importante frisar que não pode haver descontinuidade da contagem do tempo, ou seja, atrelada a posse contínua não poderá ocorrer interrupção no tempo de posse, caso ocorra deverá iniciar-se

Diante das possíveis modalidades de usucapião implementada pelo ordenamento jurídico brasileiro é possível se fazer uma classificação em pelo menos quatro grupos levandose em conta suas especificidades, interpretação teleológica e a espécie de norma que as introduzem no ordenamento jurídico. Destarte, devem-se dividir as modalidades de usucapião em quatro grupos ou categorias, quais sejam: Extraordinária, Ordinária, Especial e Indígena.

A Usucapião Extraordinária apresenta-se sob duas modalidades: a usucapião extraordinária comum com o lapso temporal de 15 (quinze) anos e a usucapião extraordinária com redução de prazo ou qualificada cujo lapso temporal é reduzido para 10 (dez) anos.

A Usucapião Ordinária segue na mesma linha apresentando-se também sob duas modalidades: a usucapião ordinária comum com lapso temporal de 10 (dez) anos e a usucapião ordinária qualificada cujo prazo temporal é reduzido para 5 (cinco) anos.

Já a usucapião Especial por ser dividida ainda em Especial Constitucional e Especial estrito sensu. Cabe ressaltar que muitos doutrinadores classificam genericamente a usucapião especial como sinônimo da usucapião constitucional, referindo-se apenas quanto à classificação a modalidade de usucapião especial ou constitucional. Entretanto, é importante diferenciar a usucapião especial constitucional que abarca apenas as modalidades de usucapião individual urbana do Art. 182 e a individual rural do Art. 191. Desta forma, as modalidades de usucapião coletiva e familiar não são contempladas pela constituição, sendo, portanto, provenientes de inovações do legislador infraconstitucional; no primeiro caso pela Lei ${ }^{\circ} 10.257 / 01$ - Estatuto da Cidade, e no segundo caso pela Lei $n^{\circ}$ 12.424/2011 que introduziu o Art. 1.240-A ao Código 
Civil Brasileiro.

E, por fim, a usucapião indígena, modalidade específica para determinado grupo de pessoas, os índios, sejam eles integrados ou não. Foi introduzida no ordenamento jurídico pátrio através do Estatuto do Índio, Lei no 6.001/73 em seu artigo 33.

\section{O PROCESSO DE DESJUDICIALIZAÇÃO NO BRASIL}

Nos últimos anos houve um aumento quantitativo das demandas judiciais fomentadas pelo contínuo processo de amadurecimento da democracia, levando o cidadão ao pleno exercício de seus direitos e utilizando-se do judiciário para sua garantia. Esse aumento gerou uma sobrecarga no sistema judiciário, resultando na morosidade e, consequentemente, na falta de efetividade deste sistema. Segundo matéria divulgada no Estadão sobre o relatório do Conselho Nacional de Justiça de 15/09/2015, apenas 28,6\% dos quase 100 milhões de processos que tramitaram em 2014 foram solucionados. Em comparação a 2013, houve um aumento de $0,8 \%$ no índice de processos que não foram resolvidos que atualmente está em $71,4 \%{ }^{3}$

Com vistas a melhorar o atendimento e desafogar o sistema judicial, o processo de desjudicialização vem ganhando espaço no Brasil. Alguns institutos foram ampliados, possibilitando às partes resolver a demanda de forma extrajudicial, ou seja, através de um processo administrativo utilizando para tanto os serviços das serventias extrajudiciais. Como exemplo, tem-se o divórcio, a separação, o inventário e partilha, e ainda, a regularização fundiária e a retificação de registro.

No ordenamento jurídico brasileiro, a primeira possibilidade de aplicação da demanda extrajudicial surgiu com a Lei $n^{\circ} 10.931 / 2004$, que ampliou a competência do oficial de Registro imobiliário nos casos de retificação, prevendo em seu artigo 213 que o Oficial será responsável pelo procedimento administrativo e suas etapas (Art. 213, Lei nº 10.931/2004).

Em 2007, o legislador ampliou o rol trazendo a via administrativa como opção para as demandas de divórcio e separação (Art. 1.124-A CPC/73), partilha e inventário (Art. 982, CPC/73) possibilitando o tratamento por essa via, através da Lei $\mathrm{n}^{\circ} 11.441 / 2007$, onde tais institutos, cumprindo os requisitos de consensualidade, prazos legais e algumas especificidades

\footnotetext{
${ }^{3}$ Carvalho, Marco Antônio. Congestionamento do Judiciário aumenta e processos pendentes já são mais de 70 milhões. Disponível em: < http://politica.estadao.com.br/blogs/fausto-macedo/congestionamento-do-judiciarioaumenta-e-processos-pendentes-ja-sao-mais-de-70-milhoes/ > . Acesso em: 22 mar. 2016.
} 
de cada caso, serão reconhecidos através da via extrajudicial por notários e registradores.

Atualmente, o instituto que entrou para o grupo de possibilidades extrajudiciais, conforme citado alhures, foi o da usucapião. A Lei 13.105/2015 trouxe inovação quando criou a opção de que seu reconhecimento seja feito através da via administrativa/extrajudicial, sendo processado diretamente no cartório do registro de imóveis da Comarca em que o imóvel está localizado (Art. 1.071, Lei 13.105/2015). Importante ressaltar que tal possibilidade não obsta que a parte o requeira pela via judicial.

Segundo Brandelli (2016, p. 30), “O procedimento de usucapião extrajudicial é um processo administrativo, conduzido por uma autoridade administrativa, que o preside, analisa o conjunto probatório, e, ao final, defere ou denega."

Importante ressaltar que anteriormente a edição da lei 13.105/2015, já existia a possibilidade do reconhecimento da usucapião extrajudicial, todavia, exclusivamente nos procedimentos de regularização fundiária de interesse social urbano, prevista pela Lei $n^{\circ}$ 11.977/2009. Esta lei, visando à regularização de assentamentos irregulares, ocupados predominantemente por populações de baixa renda, traz a titulação aos seus ocupantes de modo a garantir o direito social à moradia, o pleno desenvolvimento das funções sociais da propriedade urbana e o direito ao meio ambiente ecologicamente equilibrado.

Neste cenário, o detentor do título de legitimação de posse, concedido após averbação do auto de demarcação urbanística e do registro do projeto de parcelamento (artigo 58 da lei 11.977/2009), pode requerer ao oficial de registro de imóveis a conversão do registro deste em registro de propriedade, depois de transcorrido o prazo de 05 (cinco) anos, apresentando os demais documentos comprobatórios do cumprimento dos pressupostos legais específicos (artigo 60, $\S 1^{\circ}$, da LRP) para o reconhecimento da usucapião especial urbana (artigo 60 da lei $11.977 / 2009)$.

Oportuno esclarecer que, inicialmente, a única modalidade de usucapião passível de reconhecimento pela via extrajudicial no procedimento de regularização fundiária era a especial individual urbana, prevista no artigo 183 da CFB, pois limitada a área usucapida a $250 \mathrm{~m}^{2}$. Entretanto, a Lei n 12.424/11 estendeu-se a possibilidade da usucapião imobiliária extrajudicial para as demais modalidades, cuja área seja, individualmente, superior aos $250 \mathrm{~m}^{2}$, e, desde que sejam preenchidos os demais requisitos legais específicos e o lapso temporal, respectivo a cada modalidade (Art. 60, §3º , da LRP). 


\section{RECONHECIMENTO DA USUCAPIÃO PELA VIA EXTRAJUDICIAL}

A possibilidade do reconhecimento da usucapião pela via extrajudicial, através de processo administrativo realizado diretamente no registro de imóveis, foi introduzida no ordenamento jurídico brasileiro pelo novo Código de Processo Civil (Lei n ${ }^{\circ}$ 13.105/15), incluindo o artigo 216-A na Lei de Registros Públicos (LRP), Lei nº 6.015/73.

É sem dúvida um grande avanço no caminho de garantir a celeridade no reconhecimento estatal de um direito já adquirido por disposição legal ou constitucional, a depender da modalidade de usucapião, mas, que necessita deste reconhecimento estatal para a substituição dominial no assentamento registral. Desta forma, se reconhece a mutação da condição de possuidor em proprietário, ampliando os poderes do titular sobre o imóvel, que agora, além de gozar, usar e usufruir, poderá reivindicar como proprietário, e ainda, livremente gravar e dispor com fundamento de sua propriedade registrada no fólio real imobiliário.

Como já frisado anteriormente, neste processo brasileiro de desjudicialização, as serventias extrajudiciais é o locus adequado para proporcionar, além da celeridade procedimental, a redução dos custos da máquina judiciária e maior acesso à justiça. Acesso, inclusive, no sentido de proximidade, isto é, de facilidade de localização, acessibilidade física, porta de entrada. Mas, que consequentemente se refletirá, no acesso à justiça esculpido na Constituição, de atendimento e satisfação de uma demanda por uma decisão estatal eficaz dentro de um prazo razoável, devido ao próprio caráter privado na prestação dos serviços públicos notariais e registrais.

As serventias extrajudiciais, sem se afastar dos princípios que norteia a função pública, imprimem segurança jurídica aos atos praticados, e ainda, possuem a capilaridade para aumentar consideravelmente o locus de realização do procedimento de reconhecimento da usucapião, tais como todos os demais atos e procedimentos desjudicializados e atribuídos aos cartórios.

Com sua estrutura administrativa privada, pautada na eficiência do atendimento e instaladas em local de fácil acesso, ${ }^{4}$ e ainda, procedimental e processualmente enxuta, com prazos exíguos para cumprimento dos atos e procedimentos processuais, as serventias

\footnotetext{
${ }^{4}$ Art. $4^{\circ}$ Os serviços notariais e de registro serão prestados, de modo eficiente e adequado, em dias e horários estabelecidos pelo juízo competente, atendidas as peculiaridades locais, em local de fácil acesso ao público e que ofereça segurança para o arquivamento de livros e documentos.
} 
extrajudiciais tem as condições necessárias para imprimir a celeridade processual requerida ao cumprimento da garantia constitucional da razoável duração do processo (art. $5^{\circ}$, inciso LXXXVIII, CRFB).

Chaves e Rezende (2011, p. 11-77) ao discorrerem sobre o assunto, constatam que os notários promovem uma justiça pragmática e preventiva, a justiça notarial, evitando a formação de litígios e proporcionando uma solução mais célere e adequada. Já os registradores, por sua vez, promovem a justiça registral, por meio da publicidade, especificidade e continuidade, além de ter normas rígidas para a alteração de suas tábulas, garantindo segurança aos negócios e também eficácia às relações jurídicas noticiadas.

Destarte, a desjudicialização do processo de reconhecimento estatal da usucapião merece elogios, principalmente por possibilitar a regularização dominial de diversos proprietários de fato e de direito, mas sem a possibilidade de correção da tábula registral, seja por não possuir um justo título categorizado pelo próprio Estado, seja por possuí-lo, mas com algum vício formal que o impeça de ingressar na matrícula do imóvel ou por violar algum princípio registral como a continuidade. ${ }^{5}$

Percebe-se do mandamento legal que o legislador tornou o procedimento de reconhecimento bipartido. Isto é, para se valer da via extrajudicial para o reconhecimento estatal da usucapião, é necessário que o interessado se utilize de duas serventias extrajudiciais, cujas funções são distintas. Deve primeiramente dirigir-se ao tabelionato de notas, onde requererá uma ata notarial, atestando o tempo de posse ad usucapionem do requerente e seus antecessores, que só pode ser confeccionada por um tabelião, e posteriormente, de posse da ata notarial se dirigirá ao registro de imóveis, onde requererá a autuação de processo administrativo visando o reconhecimento da usucapião, utilizando-se a ata notarial para instruir, juntamente com outros documentos, o requerimento.

Foi necessário esse esclarecimento para a percepção da segurança jurídica atribuída a esse reconhecimento estatal por envolver, necessariamente, dois profissionais do direito; dotados de fé pública; delegados do poder público no exercício das atividades notariais e registrais; e ainda, fiscalizados, controlados e sancionados funcionalmente pelo poder judiciário $\left(\right.$ Lei n $\left.^{\circ} 8.935 / 94\right){ }^{6}$

\footnotetext{
${ }^{5}$ A violação ao princípio da continuidade pode ocorrer, por exemplo, quando o título anterior não foi registrado ou alguma qualificação, seja objetiva (do imóvel) ou subjetiva (dos titulares) foi alterada e não averbada na matrícula, devendo cumpri-los antes de ingressar com o atual título.

${ }^{6}$ A Lei no 8.935/94 também conhecida como a Lei dos Notários e Registradores (LNR), ou ainda, denominada
} 
Sendo assim, fica evidenciada que a desjudicialização do reconhecimento da usucapião foi um grande avanço para o povo brasileiro, buscando a necessária efetividade das normas que disciplinam a usucapião e que se tornavam obsoletas por ser operacionalizada apenas pelo poder judiciário já abarrotado de processos jurisdicionais, cujas demandas se tornavam prioritárias quando comparada aos processos por reconhecimento da usucapião. Desta forma, processos que duravam até 15 anos para serem solucionados, poderão durar apenas 4 (quatro) meses pela via extrajudicial. Como já ocorre nos processos de retificação de área que demanda a mesma tramitação.

\section{A CAPILARIDADE DAS SERVENTIAS EXTRAJUDICIAIS}

Um processo facilitador deve conservar suas características facilitadoras em todos os seus aspectos. O que se quer demonstrar com tais palavras é que a implementação do procedimento de reconhecimento da propriedade através da usucapião extrajudicial, chega ao ordenamento jurídico a fim de proporcionar além da celeridade, redução dos custos da máquina judiciária e maior acesso à justiça. Acesso no sentido de proximidade, isto é, de facilidade de localização, acessibilidade física, porta de entrada. Mas, que consequentemente se refletirá, no acesso à justiça esculpido na Constituição, de atendimento e satisfação de uma demanda por uma decisão estatal eficaz dentro de um prazo razoável.

As serventias extrajudiciais é o locus adequado para proporcionar tais condições, sem se afastar dos princípios que norteia a função pública e imprimem segurança jurídica aos atos praticados. Possuem a capilaridade para aumentar consideravelmente o locus de realização do procedimento de reconhecimento da usucapião e a estrutura privada, e, processualmente enxuta, para imprimir a celeridade necessária ao cumprimento da garantia constitucional da razoável duração do processo, administrativo ou judicial (art. 5º inciso LXXXVIII, CRFB).

Diante desta análise, pode-se inferir pela tabela abaixo, que existem um total de 13.774 serventias extrajudiciais no Brasil. A maior concentração encontra-se na região sudeste do país com 5.318 serventias, equivalente a $41,9 \%$ do total de unidades no território, seguindo a

pela própria lei como "Lei dos Cartórios", (mas, neste caso, não utilizada pelos doutrinadores), regulamenta o artigo 236 da constituição federal de 1988 dispondo sobre os serviços notariais ou de registro. Se tornou um verdadeiro estatuto da categoria, pois dispõe entre outras matérias: das atribuições e competências, da responsabilidade civil e criminal, das incompatibilidades e dos impedimentos, dos direitos e deveres, das infrações disciplinares e das penalidades e da fiscalização pelo poder judiciário em relação aos notários e oficiais de registros. 
distribuição populacional por região com $41,9 \%$ da população brasileira, com cerca de 85 milhões de habitantes nesta região. É possível se aferir também a quantidade populacional, em média, por serventia extrajudicial. Onde numa média nacional, tem-se que há no Brasil uma serventia extrajudicial para cada 14,8 mil pessoas. Quando se analisa regionalmente este quantitativo percebe-se alterações. Verificando-se um melhor acesso populacional às serventias na região sul, com uma média de uma serventia para cada 12,6 mil pessoas. E uma pior situação na região nordeste com uma média de 19 mil pessoas por serventia.

Tabela 1 - Distribuição de serventias extrajudiciais X População segundo região do país:

\begin{tabular}{|c|c|c|c|c|c|}
\hline \multirow{2}{*}{ Região do País } & \multicolumn{2}{|c|}{ Cartórios } & \multicolumn{2}{c|}{ População (IBGE 2015) } & População x Cartório \\
\cline { 2 - 6 } & Quantidade & $\%$ & Quantidade & \% & Quantidade \\
\hline Centro-Oeste & 966 & $7,0 \%$ & 15.442 .232 & $7,6 \%$ & $\mathbf{1 5 . 9 8 6}$ \\
\hline Nordeste & 4.257 & $30,0 \%$ & 56.560 .081 & $27,7 \%$ & $\mathbf{1 3 . 2 8 6}$ \\
\hline Norte & 921 & $6,9 \%$ & 17.472 .636 & $8,5 \%$ & $\mathbf{1 8 . 9 7 1}$ \\
\hline Sudeste & 5.318 & $38,6 \%$ & 85.745 .520 & $41,9 \%$ & $\mathbf{1 6 . 1 2 3}$ \\
\hline Sul & 2.312 & $16,8 \%$ & 29.230 .180 & $14,3 \%$ & $\mathbf{1 2 . 6 4 2}$ \\
\hline Total & $\mathbf{1 3 . 7 7 4}$ & $100,0 \%$ & $\mathbf{2 0 4 . 4 5 0 . 6 4 9}$ & $\mathbf{1 0 0 , 0 \%}$ & $\mathbf{1 4 . 8 4 3}$ \\
\hline
\end{tabular}

Fonte: CNJ e IBGE. Elaboração Própria (2016).

Entretanto, se realizada esta mesma análise em comparação a disponibilização das unidades judiciais, percebe-se que a quantidade e capilaridade das serventias é extremamente maior que as comarcas judiciais.

A proximidade da serventia extrajudicial com a população não decorre apenas do número de unidades espalhadas pelo país, mas também de sua capilaridade, ou seja, elas estão presentes em localidades não alcançadas pelos órgãos do poder judiciário. Vejamos no quadro a seguir:

Tabela 2: Representação das serventias extrajudiciais frente a população - Região Sudeste

\begin{tabular}{|c|c|c|c|c|c|c|c|c|}
\hline \multirow{2}{*}{$\begin{array}{c}\text { Unidade da } \\
\text { Federação }\end{array}$} & \multicolumn{2}{|c|}{$\begin{array}{c}\text { Serventias } \\
\text { Extrajudiciais } \\
\text { Cadastradas e Ativas }\end{array}$} & \multicolumn{2}{|c|}{ Comarcas } & \multicolumn{2}{c|}{ Municípios } & \multicolumn{3}{c|}{ População } \\
\cline { 2 - 10 } & Quant. & $\%$ & Quant. & $\%$ & Quant. & $\%$ & Quant. & $\%$ \\
\hline Espírito Santo & 357 & $6,7 \%$ & 108 & $13,5 \%$ & 78 & $4,7 \%$ & 3.929 .911 & $4,6 \%$ \\
\hline Minas Gerais & 3.009 & $56,6 \%$ & 296 & $37,0 \%$ & 853 & $51,1 \%$ & 20.869 .101 & $24,3 \%$ \\
\hline Rio de Janeiro & 406 & $7,6 \%$ & 81 & $10,1 \%$ & 92 & $5,5 \%$ & 16.550 .024 & $19,3 \%$ \\
\hline
\end{tabular}

${ }^{7}$ Dados levantados junto ao CNJ e IBGE. 


\begin{tabular}{|c|c|c|c|c|c|c|c|c|}
\hline São Paulo & 1.546 & $29,1 \%$ & 316 & $39,5 \%$ & 645 & $38,7 \%$ & 44.396 .484 & $51,8 \%$ \\
\hline Total & $\mathbf{5 . 3 1 8}$ & $\mathbf{1 0 0 , 0 \%}$ & $\mathbf{8 0 1}$ & $\mathbf{1 0 0 , 0} \%$ & $\mathbf{1 . 6 6 8}$ & $\mathbf{1 0 0 , 0 \%}$ & $\mathbf{8 5 . 7 4 5 . 5 2 0}$ & $\mathbf{1 0 0 , 0 \%}$ \\
\hline
\end{tabular}

Fonte: CNJ e IBGE. Elaboração Própria (2016). ${ }^{8}$

Fazendo um comparativo entre os dados levantados, é possível observar que as serventias extrajudiciais estão mais próximas da população. Em levantamento feito na região sudeste, verifica-se que há uma serventia extrajudicial para cada 16 mil habitantes, enquanto que em relação às comarcas esse número sobe para 107 mil habitantes, ou seja, enquanto se tem uma comarca concentrando seu atendimento em determinada região, os cartórios atendem esta mesma região distribuídas em 7 (sete) sub-regiões. Por exemplo, em uma determinada região abranja 7 (sete) municípios diferentes, será atendida por uma comarca que, em regra, se instalará no munícipio mais populoso, enquanto em cada um dos municípios haverá uma serventia extrajudicial para o atendimento direto à população.

Esse exemplo fica claro quando a análise leva em conta a quantidade de municípios. Na região analisa são 1.668 municípios, com 5.318 cartórios e 801 comarcas judiciais. Sendo assim, existem em média 3 cartórios por município, enquanto a metade dos municípios desta região não tem nenhuma unidade judiciária. Ou seja, são mais de 800 municípios sem uma unidade física de acesso pela população. Sendo obrigados, portanto, caso queiram buscar acessar à justiça, deslocar-se para outros municípios. Desta forma, as serventias judiciais funcionam como um longa manus nestas regiões desprovidas de unidades judiciais.

Fica evidente, portanto, numa análise sob o viés da capilaridade das serventias extrajudiciais ser sete vezes superior às unidades disponibilizadas pelo poder judiciário que há maior amplitude do acesso da população aos serviços disponibilizados no âmbito das serventias. Sendo certo que os serviços desjudicializados para os cartórios estarão mais acessíveis à população, principalmente as mais carentes e vulneráveis residentes nas cidades menores e distantes das regiões metropolitanas, que é onde, em regra, se instalam os serviços judiciais.

\section{A QUESTÃO DO SILÊNCIO COMO DISCORDÂNCIA}

Neste momento do trabalho se analisará a questão basilar objeto de todo fundamento anteriormente apresentado. A questão agora analisada tem o condão de, em apenas uma

\footnotetext{
${ }^{8}$ Dados levantados juto ao CNJ; IBGE e aos Tribunais de Justiça do ES; MG; RJ e SP.
} 
afirmação, sepultar todos os benefícios e esperanças de efetivação de desjudicialização da usucapião até agora apresentada.

Ocorre que o pedido de reconhecimento extrajudicial de usucapião, que será processado diretamente perante o cartório do registro de imóveis da comarca em que estiver situado o imóvel usucapiendo, deve ser instruído, dentre outros documentos ${ }^{9}$, com a planta e memorial descritivo que deverá ser assinado por profissional legalmente habilitado, com prova de anotação de responsabilidade técnica no respectivo conselho de fiscalização profissional, e ainda, "pelos titulares de direitos reais e de outros direitos registrados ou averbados na matrícula do imóvel usucapiendo e na matrícula dos imóveis confinantes” (art. 216-A, inciso II, Lei $n^{\circ}$ 6.015/73, grifo nosso).

Percebe-se, portanto, diante da exigência da assinatura na planta e no memorial descritivo dos titulares de direitos reais e de outros direitos registrados ou averbados na matrícula do imóvel objeto da usucapião, e ainda, na matrícula dos imóveis confinantes, a consequente necessidade de anuência destes para o processamento da usucapião extrajudicial. Até então, é natural e compreensível o recrudescimento burocrático imposto pelo legislador para o processo de reconhecimento da usucapião extrajudicial, devido a alteração do titular do reconhecimento, que neste caso, no lugar do magistrado será o oficial de registro de imóveis competente pela circunscrição do imóvel usucapiendo.

Diante, destes termos, até agora apresentados, não causaria nenhum prejuízo ao processo extrajudicial, as soluções comuns, dadas pelo ordenamento jurídico brasileiro, quando da impossibilidade de localização, ou mesmo da inércia quando notificados, destes titulares de direitos reais ou de outros direitos registrados ou averbados na matrícula.

Nesse sentido, segundo o artigo 213 da Lei de Registros Públicos (Lei no 6.015/73) que trata da retificação das áreas de imóveis, onde prevê processo administrativo similar ao de reconhecimento da usucapião, dispõe que se a planta não contiver a assinatura de algum confrontante, este será notificado pelo Oficial de Registro de Imóveis competente, a requerimento do interessado, para se manifestar em quinze dias, promovendo-se a notificação pessoalmente ou pelo correio, com aviso de recebimento, ou, ainda, por solicitação do Oficial

\footnotetext{
${ }^{9}$ Além do já citado será exigido ainda para a instrução do processo extrajudicial: a ata notaria lavrada pelo tabelião, atestando o tempo de posse do requerente e seus antecessores, conforme o caso e suas circunstâncias; as certidões negativas dos distribuidores da comarca da situação do imóvel e do domicílio do requerente; e, o justo título ou quaisquer outros documentos que demonstrem a origem, a continuidade, a natureza e o tempo da posse, tais como o pagamento dos impostos e das taxas que incidirem sobre o imóvel.
} 
de Registro de Imóveis, pelo Oficial de Registro de Títulos e Documentos da comarca da situação do imóvel ou do domicílio de quem deva recebê-la.

E continua dispondo que não sendo encontrado o confrontante ou estando em lugar incerto e não sabido, tal fato será certificado pelo oficial encarregado da diligência, promovendo-se a notificação do confrontante mediante edital, com o mesmo prazo, publicado por duas vezes em jornal local de grande circulação. E em todos os casos, a ausência de impugnação do confrontantes, presumir-se-á sua anuência, ou seja, interpretado o silêncio como concordância (art. 213, parágrafo $4^{\circ}$, Lei no 6.015/73, redação dada pela Lei $n^{\circ} 10.931 / 04$ ).

Entretanto, quando da aprovação do artigo 1.071 do Novo CPC que introduzia o artigo 216-A (a usucapião extrajudicial) na Lei de Registros Públicos a interpretação dada pelo Senado Federal foi em sentido contrário quando da revisão do texto substitutivo aprovado na Câmara dos Deputados, alterando o texto original e interpretando o silêncio como discordância. Desta forma, esvaziando por completo a eficácia do processo pela via extrajudicial, perdendo sua utilidade prática e todos os benefícios apresentados nos tópicos anteriores deste estudo. Cabe ressaltar que ambos os textos, o do parágrafo anterior (art. 213,

$\S 4^{\circ}$ - no silêncio presume anuência), e este (art. 216-A - silêncio como discordância) estão na mesma lei e localizados, inclusive, no mesmo capítulo da Lei de Registro Públicos (Lei $\mathrm{n}^{\circ}$ 6.015/73), evidenciando a contradição criada pelo legislador. Percebe-se que a racio inicial da norma foi desvirtuada.

Portanto, os parágrafos $2^{\circ}$ e $6^{\circ}$, do artigo 216-A, da Lei $n^{\circ} 6.015 / 73$, alterado pelo Senado, e atualmente em vigor, trazem, respectivamente, os seguintes textos:

\footnotetext{
Se a planta não contiver a assinatura de qualquer um dos titulares de direitos reais e de outros direitos registrados ou averbados na matrícula do imóvel usucapiendo e na matrícula dos imóveis confinantes, esse será notificado pelo registrador competente, pessoalmente ou pelo correio com aviso de recebimento, para manifestar seu consentimento expresso em 15 (quinze) dias, interpretado o seu silêncio como discordância (grifo nosso).

Transcorrido o prazo [...], sem pendência de diligências [...] e achando-se em ordem a documentação, com inclusão da concordância expressa dos titulares de direitos reais e de outros direitos registrados ou averbados na matrícula do imóvel usucapiendo e na matrícula dos imóveis confinantes, o oficial de registro de imóveis registrará a aquisição do imóvel com as descrições apresentadas, sendo permitida a abertura de matrícula, se for o caso (grifo nosso).
}

Desta forma, evidencia-se que o legislador ressalta nos dois parágrafos a necessidade de consentimento expresso dos titulares de direitos reais e outros direitos registrados e 
averbados na matrícula do imóvel usucapiendo e na matrícula dos imóveis confrontantes.

Por todo caminho traçado por este estudo até o momento, conclui-se pela inexplicável posição dos legisladores do Senado Federal. Pois, com apenas uma afirmação contrária ao próprio costume e aos entendimentos legislativos positivados anteriormente, pôs fim a efetividade que se poderia alcançar através da usucapião extrajudicial, além de retornar para a máquina judiciária toda a demanda por reconhecimento da usucapião.

Destarte, verifica-se que a mudança do texto legal feita pelo Senado, no intuito de prover mais segurança jurídica, na verdade, acabou por limitar o direito do requerente em ter seu direito satisfeito pela via extrajudicial, tendo que se valer da via judicial, mais morosa, mesmo preenchendo os requisitos legais para o reconhecimento da aquisição da propriedade pela usucapião. Soma-se a isso o fato de que interpretar o silêncio como discordância, acaba por se tornar uma afronta ao ordenamento jurídico nacional, tendo em vista que o Código Civil, em seu artigo $111^{10}$, determina que o silêncio seja visto, em regra, como concordância.

Na questão da usucapião extrajudicial, se a inércia do titular da propriedade associada à posse ad usucapionem do possuidor resultou na usucapião, como esperar que essa mesma inércia não signifique outra coisa que não indiferença em relação a propriedade.

Essa ideia é bem explicitada por Brandelli (2016, p.98), ao dizer que se algum legitimado passivo receber a notificação e não se pronunciar sobre ela durante o prazo, devese imaginar que não tem interesse em impugnar, pois se tivesse, o faria no prazo, bem como se este mesmo notificado verificar que há afronta ao seu direito, não se calará e sim impugnará, e se verificar que não há, não terá interesse em se manifestar a não ser por questões pessoais, afirmando assim, que o silencio deveria presumir a concordância e não impugnação.

Neste sentido, bem afirma Lamana Paiva (2015, p. 4 e 5):

Restará, entretanto, um problema de difícil solução na hipótese em que haja o silencio do titular do direito real sem que isso signifique propriamente discordância com a realização do procedimento ( $\$ 2^{\circ}$ do Art. 216-A), mas signifique indiferença às consequências de sua não manifestação expressa, que talvez venha a ser uma hipótese bastante recorrente no futuro, dada à forma como o procedimento foi concebido. Temos convicção, por outro lado, que as dificuldades encontradas na prática reiterada do procedimento, aliadas à possibilidade de que a matéria venha a ser regulada pelo CNJ - da mesma forma como ocorreu com a Lei ${ }^{\circ} 11.441 / 2007$ - poderão significar um aperfeiçoamento desse instituto que nasce das inovações trazidas pelo novel Código de Processo Civil.

\footnotetext{
${ }^{10}$ Assim dispõe o artigo 111 do CC, "O silêncio importa anuência, quando as circunstâncias ou os usos o autorizarem, e não for necessária a declaração de vontade expressa. ”
} 
De outra ponta, cabe consignar que com exceção da usucapião ordinária, não se exige para o reconhecimento da usucapião, justo título e boa-fé pelo usucapiente, logo, é possível afirmar que, nessas hipóteses, em regra, o antecessor não terá qualquer interesse em anuir com o procedimento, já que por tratar-se de modo originário de aquisição não há que se falar em transmissão de um proprietário a outro. Aliás, essa é a essência do instituto, modo originário aquisitivo que não depende de concordância do proprietário anterior.

É inimaginável, portanto, o legislador acreditar que por livre e espontânea vontade um detentor de direito real de propriedade, inerte e negligente no cumprimento da função social da propriedade, e que, por isso mesmo à perdeu diante da falta do pressuposto do direito de propriedade (TEPEDINO, 2012), se prontifique a assinar qualquer documento que reconheça a propriedade para outra pessoa. Esta propriedade de fato e de direito já foi transferida pela lei ou pela Constituição, bastando ao Estado reconhecê-la por estar diante de um direito subjetivo do possuidor usucapiente que cumpre uma função social. Todavia, este reconhecimento não pode levar toda uma vida. O tempo necessário para usucapir e, três vezes mais, só para ter o reconhecimento estatal.

A lição de Gustavo Tepedino (2002, p. 2) é esclarecedora em sua afirmação,

\footnotetext{
Quando se trata do direito de propriedade, entre defender o valor individual e defender o valor social, o direito brasileiro fez uma opção clara: defendeu o valor social. É por isso que a Constituição Federal, artigo $5^{\circ}$, no inciso XXII, garante o direito de propriedade, mas no inciso em seguida, o XXIII diz que "a propriedade atenderá a sua função social”.
}

Cabe ressaltar que o autor se posiciona de maneira firme no entendimento de que a Constituição inseriu a função social como pressuposto da propriedade, destarte, se uma determinada propriedade não cumpre sua função social, perde o seu título justificativo, podendo ser retirada a tutela jurídica dominial, em situações concretas de conflito, em privilégio ao possuidor que cumpre a função social, mesmo desprovido do título de propriedade (TEPEDINO, 2002, p. 40).

\section{CONSIDERAÇÕES FINAIS}

A posição dos legisladores do Senado Federal demonstrou a preocupação da proteção do direito de propriedade, mesmo que esta não cumpra sua função social ou desconfiança na 
capacidade sistema notarial e registral brasileiro em cuidar da questão no lugar do judiciário. Todavia, como já visto, estas preocupações são desprovidas de fundamento, a primeira afronta a própria Constituição da República, e a segunda, talvez por desconhecimento da estrutura jurídica que norteia o sistema registral e notarial no Brasil.

De toda sorte, se não houver mudança no texto legal a corrigir este "equívoco legislativo", haverá um retorno ao judiciário de cause todas as demandas apresentadas aos registradores de imóveis por reconhecimento da usucapião na esfera extrajudicial. Poucas se efetivarão pela via extrajudicial. Voltarão ao judiciário pelos procedimentos de dúvidas, ou mesmo, pelas vias ordinárias, retornando à estaca zero, ou seja, a situação atual.

Entretanto, no sentido de imprimir alguma eficácia e efetividade em aproveitamento na alteração legislativa em prol da desjudicialização, é importante defender a possibilidade, diante da inevitabilidade do retorno das demandas por reconhecimento das usucapiões retornarem ao judiciário, de este então aproveitar e reconhecer juridicamente os atos já praticados na esfera extrajudicial.

Nesse sentido, diante da legalidade do processo administrativo pela via extrajudicial, é possível a adoção de um processo híbrido, um processo administrativo extrajudicial instrumentalizando o processo judicial.

Neste caso deverá haver a conscientização dos magistrados para aproveitar todos os atos, perfeita e legalmente, praticados pelos notários e registradores no adiantamento procedimental da ação do reconhecimento de usucapião.

Esta orientação poderia ocorrer também através do Conselho Nacional de Justiça (CNJ) ou através das Corregedorias Gerais de Justiças dos Tribunais de Justiça dos estados. Onde se poderia cumprir todos os procedimentos necessários extrajudicialmente pelos notários registradores (através das atas notarias, escrituras declaratórias, notificações aos particulares e poder público, mediações, acordos, conciliações, levantamentos das certidões, documentos, diligências e etc.) apondo a fé pública sobre os atos realizados e, afinal, o requerente ingressa em juízo para o cumprimento somente daquilo que, realmente, não foi possível resolver na via extrajudicial, como por exemplo, a anuência expressa de um dos titulares de direitos reais ou outros direitos como destacado na lei. Podendo, nesta esfera, seu silêncio ser interpretado como concordância.

Portanto, conclui-se pela ineficácia da usucapião extrajudicial, como disposta pela lei, por retirar do registrador a possibilidade do reconhecimento da usucapião diante da ausência 
expressa de concordância de qualquer um dos titulares de direitos reais ou de outros direitos registrados ou averbados na matrícula do imóvel usucapiendo ou nas matrículas dos imóveis confrontantes.

Desta forma, até que venha uma inovação legislativa para alterar a já ineficaz usucapião extrajudicial, conforme disposta, por processualmente não respeitar, sequer a essencialidade do instituto, o poder judiciário continuará sendo o protagonista desta história, que poderá caminhar na mesma velocidade que hoje, ou poderá ser acelerada se utilizar-se das ferramentas extrajudiciais para dinamização de suas decisões, reconhecendo a possibilidade de um processo híbrido e harmônico. 


\section{BIBLIOGRAFIA}

ALVES, Saudi Junior. O novo CPC e o "Usucapião Extrajudicial". 2015. Disponível em: <http://saudi.jusbrasil.com.br/artigos/257062097/o-novo-cpc-e-o-usucapiao-extrajudicial>. Acesso em: 16 fev. 2016.

ASCENSÃO, José de Oliveira. Direito Civil - Reais. 5. ed. Coimbra: Coimbra Ed., 2000. p.414.

BRANDELLI, Leonardo. Usucapião administrativa: De acordo com o novo código de processo civil. São Paulo: Saraiva. 2016.

BRASIL. Lei nº 13.105 de 16 de março de 2015. Altera o Código de Processo Civil. Brasília, DF, 16 mar. 2015. Disponível em: <http://www.planalto.gov.br/ccivil_03/_ato20152018/2015/lei/113105.htm>. Acesso em: 12 fev. 2016.

CARVALHO, Marco Antônio. Congestionamento do Judiciário aumenta e processos pendentes já são mais de 70 milhões. Estadão. São Paulo. 15 set. 2015. Disponível em <http://politica.estadao.com.br/blogs/fausto-macedo/congestionamento-do-judiciarioaumenta-e-processos-pendentes-ja-sao-mais-de-70-milhes/>. Acesso em 26 fev. 2016.

CARVAlHO FILHO, José dos Santos. Comentários ao Estatuto da Cidade. 5. ed. rev. ampl. atual. São Paulo: Atlas, 2013.

CHAVES, C.F.B; REZENDE, Afonso Celso. Tabelionato de notas e o notário perfeito. 6. ed. Campinas: Millenium, 2011.

CORRÊA, Cláudia Franco; BAPTISTA, Bárbara Gomes. A desjudicialização da Usucapião Imobiliária: Entre a promessa e as dúvidas. 2015. Disponível em: <http://www.conpedi.org.br/publicacoes/c178h0tg/aynm5hh3/U5wH56WuBjPcL8J4.pdf.>.

Acesso em: 15 fev. 2016.

DONIZETTI, Elpídio. Curso didático de direito processual civil - 18. ed. rev. ampl. atual, especialmente de acordo com as Leis no 12.424/2011,12.431/2011 e Lei n ${ }^{\circ} 12.810 / 2013$ - São Paulo: Atlas, 2014.

DORNELLES, Daniélle; JÚNIOR, Flávio Cassel. A viabilidade da usucapião extrajudicial no ordenamento jurídico brasileiro. 2015. Disponível em: <http://online.unisc.br/acadnet/anais/index.php/sidspp/issue/view/56>. Acesso em: 15 fev. 2016.

TARTUCE, Flávio. Manual de direito civil : volume único. 4. ed. rev. atual. ampl. Rio de Janeiro : Forense; São Paulo: MÉTODO, 2014. 
GAVAZZI, Douglas. A usucapião extrajudicial, um nascituro quase obsoleto. 2015. Disponível em: <http://www.notariado.org.br/index.php?pG=X19leGliZV9ub3RpY2lhcw $==\&$ in $=$ NTYwNg==>. Acesso em: 16 fev. 2016.

GOMES, Orlando. Direitos Reais. 21 ed. ver. atual. / por Luiz Edson Fachin. Rio de Janeiro : Forense. 2012.

GONÇALVES, Carlos Roberto. Direito Civil Esquematizado, v.2 / Carlos Roberto Gonçalves; Coordenador Pedro Lenza. 3. ed. São Paulo : Saraiva, 2015.

OLIVEIRA, Fernanda Loures. Usucapião Administrativa: uma alternativa possível. Revista dos Tribunais Online. Revista de Direito Privado. Vol.48. p. 129. 2011. Disponível em: <https://professorhoffmann.files.wordpress.com/2012/07/usucapic3a3o-administrativa-umaalternativa-possc3advel-fernanda-loures-de-oliveira-2011.pdf>. Acesso em: 15 fev. 2016.

PAIVA, João Pedro Lamana. Novo CPC introduziu a usucapião extrajudicial no país. 2015. Disponível em: http://www.irib.org.br/files/obra/Versa771o_correta_Artigo_Lamana_ Paiva_Usucapiao.pdf>. Acesso em: 16 fev. 2016.

PEREIRA, Felipe Pires. A interpretação do silêncio na usucapião extrajudicial do novo CPC. Revista Consultor Jurídico. Disponível em: <http://www.conjur.com.br/2016-jan09/interpretacao-silencio-usucapiao-extrajudicial-cpc>. Acesso em: 15 fev. 2016.

SCAVONE JUNIOR, Luiz Antônio. Direito Imobiliário - Teoria e prática. 9. ed. rev. atual. ampl. Rio de Janeiro : Forense, 2015.

VENOSA. Silvio de Salvo. Direito Civil: Direitos Reais. 13.ed. São Paulo : Atlas, 2013. (Coleção Direito civil; v.5)

VIANA JUNIOR, Dorival. A usucapião extrajudicial no novo CPC brasileiro. 2015. Disponível em: <http://www.novocpcbrasileiro.com.br/a-usucapiao-extrajudicial-no-novocpc-brasileiro/>. Acesso em: 16 fev. 2016. 